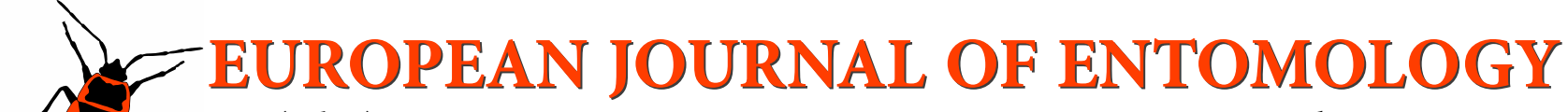 \\ ISSN (online): 1802-8829 \\ http://www.eje.cz \\ Eur. J. Entomol. 116: 362-371, 2019 \\ doi: 10.14411/eje.2019.038 \\ ORIGINAL ARTICLE
}

\section{Laboratory breeding of Korynetes caeruleus (Coleoptera: Cleridae) for the biological control of Anobium punctatum (Coleoptera: Ptinidae)}

\author{
Tilo HAUStein ${ }^{1}$, Sabine BUSWeiler ${ }^{2}$, Vera HAUSTEIN ${ }^{1}$, Claudia von LAAR $^{3}$ and Rudy PlaRRE ${ }^{2, *}$ \\ ${ }^{1}$ Sachverständigenbüro Haustein, Königsteinstraße 8, 01277 Dresden, Germany; e-mail: info@dr-haustein.com \\ 2 Bundesanstalt für Materialforschung und -prüfung (BAM), Biologische Materialschädigung und Referenzorganismen, \\ Unter den Eichen 87, 12205 Berlin, Germany; e-mails: sabine.busweiler@bam.de, ruediger.plarre@bam.de \\ ${ }^{3}$ Hochschule Wismar, University of Applied Sciences, Technology, Business and Design, Faculty of Engineering, \\ Civil Engineering, Philipp-Müller-Straße 14, 23952 Wismar, Germany; e-mail: claudia.von_laar@hs-wismar.de
}

Key words. Coleoptera, Cleridae, Korynetes caeruleus, Ptinidae, Anobium punctatum, biological pest control, life history data, laboratory breeding, wood protection, cultural heritage

\begin{abstract}
Larvae and adults of Korynetes caeruleus (de Geer 1775) (Coleoptera: Cleridae) were collected from old churches and reared in the laboratory on Anobium punctatum (de Geer 1774) (Coleoptera: Ptinidae). Breeding success of K. caeruleus was low, but basic parameters of this species' developmental cycle were identified. At $21^{\circ} \mathrm{C}$ and $75 \%$ relative humidity and a fourmonth cold period at $4^{\circ} \mathrm{C}$, the development of $K$. caeruleus from egg to adult appearance lasted 2 years. The pupal stage may be reached and completed after one and a half years. Feeding on larvae of $A$. punctatum by larvae of $K$. caeruleus was observed and consisted of a combination of sucking haemolymph and consuming body parts. The sickle-like mandibles of larvae of $K$. caeruleus penetrate the cuticle of prey larvae; this is followed by pumping and sucking body movements. Adult beetles of $A$. punctatum were not attacked by $K$. caeruleus larvae. Feeding behaviour of adult $K$. caeruleus was not investigated.
\end{abstract}

\section{INTRODUCTION}

Biological control of pests is one cornerstone of Integrated Pest Management (IPM). To evaluate the potential of a predator as biological control agent of a pest species in the field, autecological studies and reliable life history data of the beneficial species are needed.

Although several parasitoids and predators of wood boring pest insects are well known (Becker, 1954; Paul et al., 2008), their utilization in biological control to protect structural timbers, wooden furniture or art is still limited and unexploited (Steidle et al., 2007; Schöller, 2010; Schöller \& Prozell, 2011; Auer \& Kassel, 2014; Biebl \& Auer, 2017; Querner, 2017). Major reason for this is the lack of detailed knowledge of their biology, absence of standard procedures for their mass rearing and reliable data on their pest control efficiency (Haustein et al., 2014). Establishing a sustainable laboratory culture of beneficial insects in order to determine their life histories is therefore an important prerequisite before promoting the use of classical biological control for the protection of wooden structures (Faulds, 1987; Reeve et al., 2003; Kassel et al., 2018).

Korynetes caeruleus (de Geer 1775) (Coleoptera: Cleridae) is known to be a predator of wood boring anobiids, in- cluding the major pest beetle Anobium punctatum (de Geer 1774) (Coleoptera: Ptinidae, formerly Anobiidae) (Becker, 1942; Vité, 1952; Hickin, 1963a, b; Belmain, 1998; Belmain et al., 1999a; Unger et al., 2001; Petzoldt, 2011). Adults of $K$. caeruleus are believed to feed on all stages (egg to imago) of $A$. punctatum (Becker, 1954). The larvae of $K$. caeruleus can consume all but the adults of $A$. punctatum when these are alive, but may be able to consume dead ones (Ott, 2007). Predators in general can feed on a variety of different prey and are present in different habitats, but $K$. caeruleus seems to be strongly associated with pests of structures made of wood. This species is mainly a synanthrope (Becker, 1954; Gerstmeier, 1998; Belmain et al., 1999b; Belmain \& Ridout, 2000; Franke, 2001; Haustein \& von Laar, 2007; Haustein et al., 2007; Noldt, 2007; Mosneagu, 2012; Niehuis, 2013) because it is rarely recorded and if ever in out-door faunistic surveys in Central and Northern Europe only in limited numbers (Alexander, 2004; Nikitsky \& Schigel, 2004; Esser \& Kielhorn, 2005; Müller et al., 2007; Ostrauskas \& Ferenca, 2010; Johansson, 2011; Niehuis, 2013; Finch 2015; Háva \& Kovařík, 2015).

\footnotetext{
* Corresponding author; e-mail: ruediger.plarre@bam.de
} 


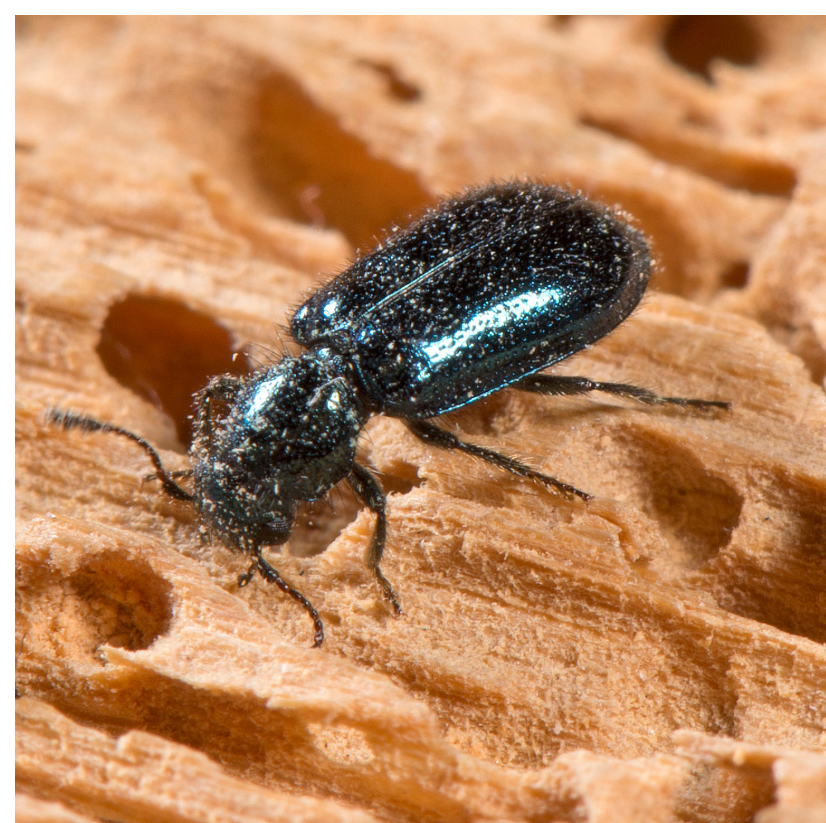

Fig. 1. Adult beetle of Korynetes caeruleus walking on soft wood infested with Anobium punctatum.

We collected adult beetles and large larvae of $K$. caerule$u s$ in old, small village churches in north-eastern Germany and fed them on a laboratory culture of A. punctatum. Although mass rearing of this predator was not achieved, this is to our knowledge the first communication on the successful reproduction of $K$. caeruleus under controlled laboratory conditions and record of reliable life history data.

\section{MATERIAL AND METHODS}

\section{Collection of $K$. caeruleus}

Korynetes caeruleus was collected from small churches in Mecklenburg-Vorpommern (north-east Germany). Many of these churches are currently not regularly used with only four to five services per year. Most of them were erected or largely restored during the late $18^{\text {th }}$ and middle $19^{\text {th }}$ century. Building materials were local boulder and cobble stones combined with bricks and wood. The interior, mainly the seating and the choir stalls, were made from wood. Today, the buildings are unheated with high relative humidity in the inside resulting in a high moisture content

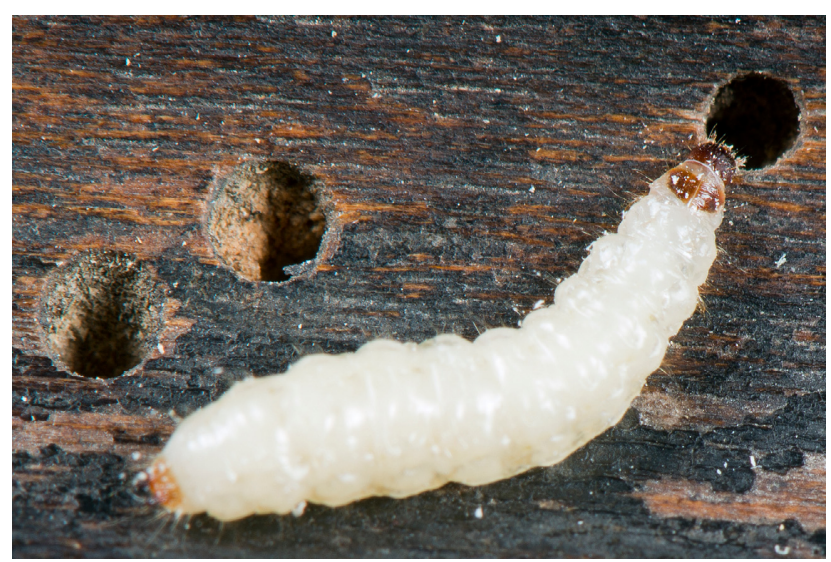

Fig. 2. Larva of Korynetes caeruleus about to enter a flight hole of Anobium punctatum.

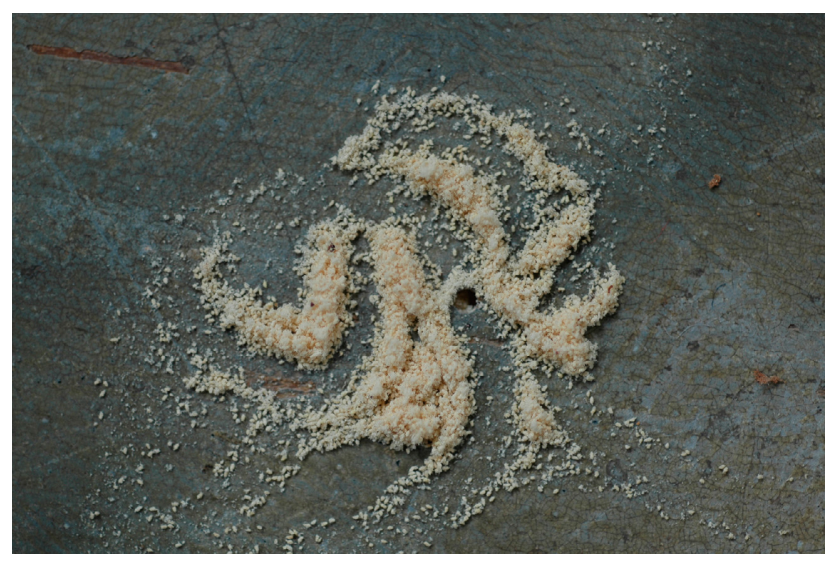

Fig. 3. Tracks of Korynetes caeruleus larvae that moved through wood worm frass thrown out by other $K$. caeruleus larvae searching for prey in flight holes of Anobium punctatum.

of the wood throughout the year (Franzen et al., 2009; Haustein, 2010). At the time when the beetles were collected in spring (see below) ambient temperatures ranged from 9.5 to $20.3^{\circ} \mathrm{C}$ (mean $14.0^{\circ} \mathrm{C}$ ), with relative humidity's of 47.5 to $67.5 \%$ (mean $54.8 \%$ ).

There are records of the occurrence of A. punctatum, K. caeruleus and other wood associated beetle species at the collection sites since 2005 (Haustein \& von Laar, 2007; Haustein, 2010). However, it is assumed that they were present earlier. According to Haustein \& von Laar (2007) high numbers of live adult beetles of $K$. caeruleus (Fig. 1) occur in churches from the beginning of May for about four weeks and then decline. They are regularly observed on the surfaces of wooden structures, where they mate. So far, they have not been detected in the woodlands surrounding these buildings. Identification of $K$. caeruleus was based on the description provided by Gerstmeier (1998), who also verified their identity (Haustein, 2010).

Late instar larvae of $K$. caeruleus occur about two to three weeks earlier in the year than the adults. They were also found on the surface of wood structures, where they presumably search for suitable prey by frequently entering and exiting from the flight holes made by their prey (Fig. 2). Wood worm (A. punctatum) frass which fills the flight holes and the connecting tunnels is ejected during this process and yellowish wood powder piles up near flight holes (Ott, 2007). Often other larvae of $K$. caeruleus, while searching the surface of wood, move through these piles of powder leaving typical tracks (Fig. 3). This kind of larval activity may last until late summer, however with declining frequency over time.

Because the occurrence of larvae and adults of $K$. caeruleus partially overlap each year, it is assumed this species takes several years to complete its development. Thus, at least two distinct generations at different developmental stages may co-occur. Adult beetles of the prey species, A punctatum, were not detected before the end of June and the beginning of July and must therefore

Table 1. Number of larvae and adults of Korynetes caeruleus collected over the period 2013 to 2017.

\begin{tabular}{ccccc}
\hline Larvae & & & \multicolumn{2}{c}{ Adult beetles } \\
\cline { 1 - 2 } \cline { 5 - 5 } Time of collection & Total $(\mathrm{n})$ & & Time of collection & Total $(\mathrm{n})$ \\
\hline 2013, May 6 & 12 & & 2013, May 6 & 14 \\
2014, May 5 & 17 & & 2014, May 5 & 54 \\
2015, May 4 & 19 & & 2015, May 11 & 60 \\
2016, May 3 & 16 & & 2016, May 13 & 54 \\
2017, May 7 & 13 & & 2017, May 24 & 50 \\
\hline
\end{tabular}


Table 2. Results of rearing field collected adult beetles of Korynetes caeruleus in five consecutive years. Life history data were recorded in terms of the developmental stages present at particular times. Only those individuals that were alive are listed. Further details in the text.

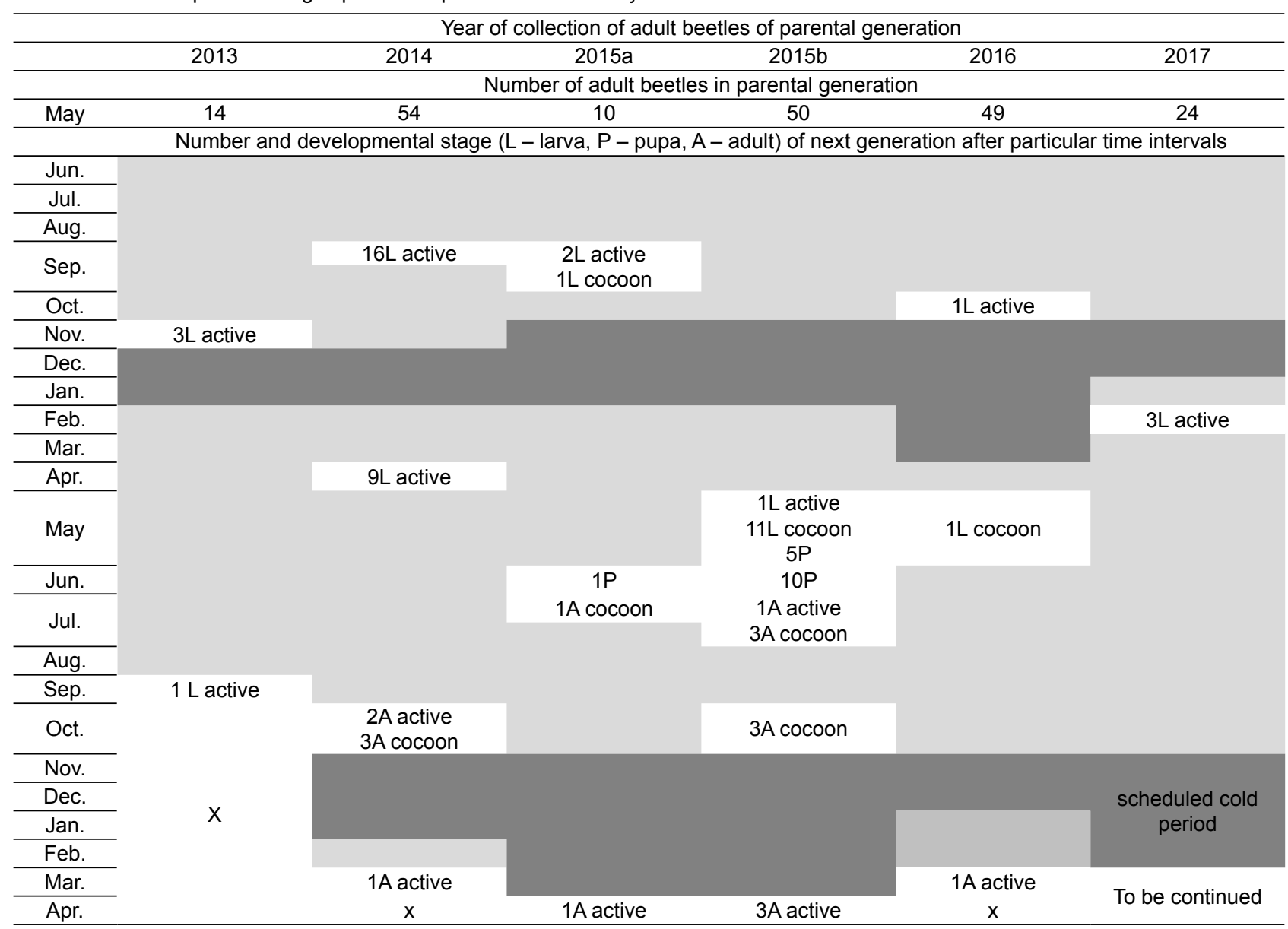

Light grey boxes indicate rearing conditions of $21 \pm 1^{\circ} \mathrm{C}$ and $75 \pm 5 \% \mathrm{r}$. $\mathrm{H}$. Dark grey boxes indicate rearing at $4^{\circ} \mathrm{C}$. White boxes indicate stages present at that time. $X$ indicates end of experiment.

be excluded as a source of food for at least the mating and egg laying adult beetles of $K$. caeruleus.

\section{Collection of $K$. caeruleus and breeding in a laboratory}

Manual collection of late instar larvae and adult beetles of $K$. caeruleus was carried out in five consecutive years from 2013 to 2017 , twice during mid and late spring for two to three days, respectively (Table 1 ). In between the mid and late spring collection dates in 2014 and 2015, a variety of traps of different designs were tested. Trap lures were made from an artificial wood-like diet containing large larvae of $A$. punctatum (see below) and oak saw dust. Unfortunately, none of these traps caught significant numbers of $K$. caeruleus. Thus, the manual collection of larvae and beetles was the only efficient method of collection.

After collection, insects were caged individually for transport to avoid cannibalism, especially among larvae. Beetles were only confined as pairs when captured in copulation. Insects were immediately transported to BAM (Federal Institute for Materials Research and Testing) in Berlin and placed in 3 to 4 months old cultures of A. punctatum larvae for further breeding (Table 2 and Table 4). First, due to the difficulties associated with determining the sex of live $K$. caeruleus, all individually transported adult beetles were collectively released into a large petri-dish of approximately $9 \mathrm{~cm}$ in diameter for mating. Pairs or groups of four to six beetles were then added to the cultures of $A$. punctatum larvae. Individuals which did not mate after collection were pooled as one group. Five to six of these adults were added to cultures of $A$. punctatum.

Combined cultures of A. punctatum / K. caeruleus were kept at $21 \pm 1{ }^{\circ} \mathrm{C}$ and $75 \pm 5 \% \mathrm{r}$. h. on an artificial wood diet as described in the standard protocols for rearing A. punctatum (Cymorek, 1965, 1975; Baker \& Bletchly, 1966). Part of that standard rearing protocol is the temporary storage of cultures for two to four months at $4^{\circ} \mathrm{C}$, when $A$. punctatum larvae reach the age of ten months. Bringing the cultures back to normal rearing conditions of $21 \pm 1{ }^{\circ} \mathrm{C}$ and $75 \pm 5 \% \mathrm{r}$. h. after cold storage triggers pupation and the development of adults in A. punctatum. It was assumed that the predator, $K$. caeruleus, needs the same abiotic conditions to complete its development, therefore, the A. punctatum / K. caeruleus cultures were treated similarly. Some of the A. punctatum / K. caeruleus cultures were examined after particular intervals of time to determine the stage of development reached by $K$. caeruleus (see white boxes in Table 2 and Table 4). The larvae of $K$. caeruleus retrieved from these cultures were reintroduced into other A. punctatum cultures of similar age.

\section{Feeding behaviour of larvae}

In addition to the rearing program, four larvae of $K$. caeruleus from the May 2016 collection continuously fed larvae of $A$. punctatum were observed for long periods of time. For this, one larva of each species (prey and predator) were confined in small Petri dishes of approximately $4 \mathrm{~cm}$ in diameter, which functioned as an arena for behavioural observation. The arena contained no 
Table 3. Number, size and weight of the larvae of Korynetes caeruleus collected from 2015 to 2017 . Same letters indicate no significant difference; not deter. - not determined.

\begin{tabular}{|c|c|c|c|c|c|}
\hline \multirow{2}{*}{ Year } & \multirow{2}{*}{ Total $(n)$} & \multicolumn{2}{|c|}{ Body size (mm) } & \multicolumn{2}{|c|}{ Body weight (mg) } \\
\hline & & $\min .-\max$ & Average \pm standard deviation & $\min .-\max$ & Average \pm standard deviation \\
\hline 2015, May 4 & 19 & $5-9$ & $6.9 \pm 1.2^{\mathrm{a}}$ & not deter. & not deter. \\
\hline 2016, May 3 & 16 & $5-9$ & $7.0 \pm 1.2^{\mathrm{a}}$ & $0.82-6.90$ & $3.3 \pm 1.6^{b}$ \\
\hline 2017, May 7 & 13 & $5-9$ & $7.5 \pm 1.4^{\mathrm{a}}$ & $0.92-5.56$ & $3.3 \pm 1.6^{b}$ \\
\hline
\end{tabular}

wood or any other kind of matrix other than a small shelter made of corrugated paper.

Life larvae of $A$. punctatum were placed in the open but were unable to move around. When they were consumed or killed by the predator they were replaced. Arenas were kept in a rearing room at $21 \pm 1^{\circ} \mathrm{C}$ and $75 \pm 5 \% \mathrm{r}$. h.

Changes in body mass of each larva of $K$. caeruleus were recorded once every month by weighing them on a Sartorius LE 225D-OCE laboratory scale to the nearest $0.01 \mathrm{mg}$ (Table 5).

For observing feeding behaviour, mainly after adding A. punctatum larvae, the arenas were carefully placed on a laboratory bench at ambient room temperature and under normal light conditions. When contact between predator and prey was established the arena was placed under a binocular for observation and the feeding behaviour recorded.

\section{Scanning electron microscope (SEM) pictures of mouthparts of $K$. caeruleus}

SEM was carried out at the University of Wismar, department of civil engineering, section building material technology, Germany. The head of a late instar larva of $K$. caeruleus with all its mouthparts was carefully straightened out and mounted on a

Table 4. Results of rearing field collected larvae of Korynetes caeruleus in five consecutive years. Life history data were recorded in terms of the developmental stages present at particular times. Only individuals recorded alive are listed. Further details in the text.

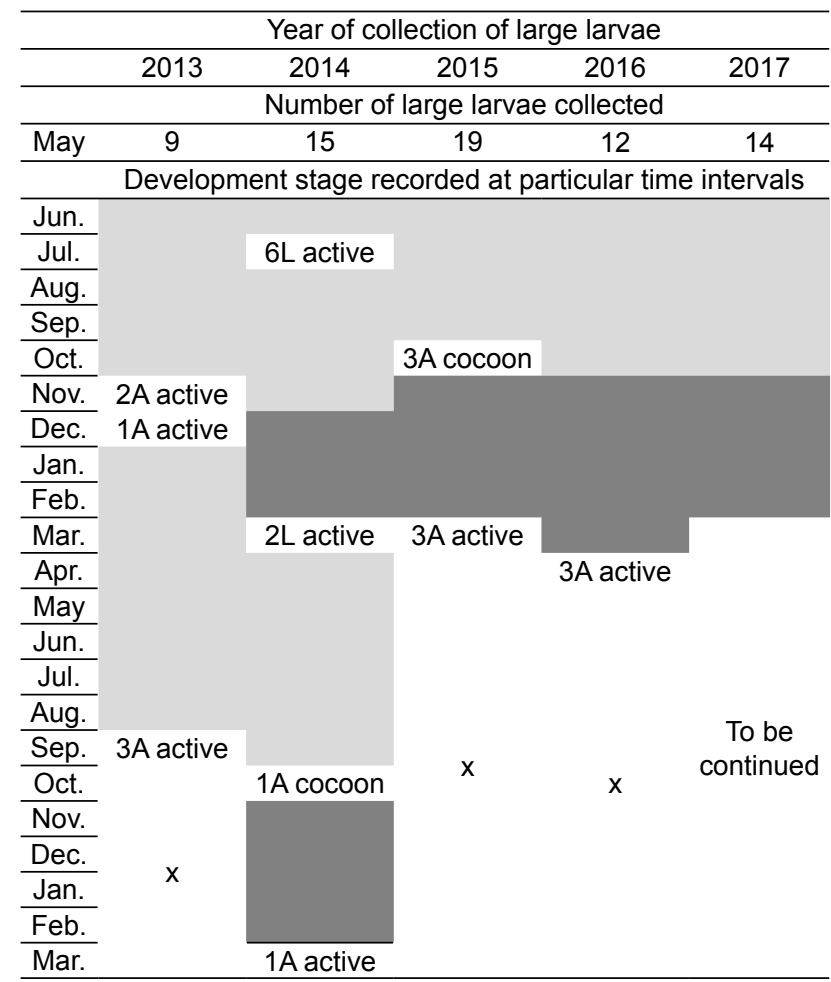

Light grey boxes indicate rearing at $21^{\circ} \mathrm{C}$ and $75 \% \mathrm{r}$. h. Dark grey boxes indicate rearing at $4^{\circ} \mathrm{C}$. White boxes indicate stages present at particular intervals of time. $\mathrm{X}$ indicates end of experiment. specimen holder stub using a conductive adhesive pad. Specimens and holder were bridged with conductive silver and finally coated with gold using a BALZERS SCD 050 Sputter Coater (BAL-TEC $\mathrm{AG})$, resulting in a coat thickness of $16 \mathrm{~nm}$. SEM pictures were taken using a FEI Quanta FEG 250 s.e.m. in high vacuum mode at a magnification of 2040 times. An Everhart Thornlay Detector was used as a secondary electron detector.

\section{RESULTS}

\section{Collection and breeding}

From previous studies it is known that larvae of $K$. caeruleus can best be collected on the surface of wooden objects inside churches from late April to early May and the adults about one to two months later (Haustein \& von Laar, 2007; Haustein, 2010). Total numbers of hand collected larvae and adult beetles are listed in Table 1. The rearing of $K$. caeruleus varied slightly over the years due to minor changes in physical handling of diets (as described above), which were adjusted as new insights were gained (see below).

\section{Rearing from beetles}

Although carried out very carefully the examinations of the $K$. caeruleus / A. punctatum cultures to record life history data, always severely damaged the cultures and stressed the individuals. Many of them did not recover and were unable to complete their development. Table 2 lists individuals that completed their development.

In 2013, fourteen beetles of $K$. caeruleus were placed in cultures of larvae of $A$. punctatum. Six months later three active $K$. caeruleus larvae of the next generation were retrieved, of which, unfortunately, just one survived to be transferred the following month to cold conditions (Table 2/2013). This larva remained dormant for two months after which it was active for another eight months, but died of unknown causes without developing further.

The breeding experiment in 2014 started with twentyseven pairs of adult beetles of $K$. caeruleus. Four months later the sixteen active larvae collected were induced to become dormant (Table 2/2014) of which nine became active when returned to standard rearing conditions. Six months later five adult beetles were found. Three of them were in cocoons (Fig. 4). Adult beetles in cocoons were transferred one month later and subjected to a second cold period for three months, after which they were kept under standard rearing conditions during which one adult beetle emerged, but the other two died.

From the 2015 collection of adult beetles thirty pairs of $K$. caeruleus were transferred to cultures of larvae of $A$. punctatum. Five cultures were examined four months later to check the numbers, size, and condition of the larvae of 
Table 5. Biometric data, development and number of larvae and adults $A$. punctatum consumed by the larvae of Korynetes caeruleus collected in the field in 2016.

\begin{tabular}{|c|c|c|c|c|c|}
\hline \multirow{2}{*}{ Date } & \multirow{2}{*}{ Recorded } & \multicolumn{4}{|c|}{ Larvae of Korynetes caeruleus } \\
\hline & & Larva 1 & Larva 2 & Larva 3 & Larva 4 \\
\hline 17.05 .16 & Initial weight (mg) & 1.9 & 3.6 & 4.0 & 6.9 \\
\hline $1^{\text {st }}$ month & Consumption of $A$. punctatum & $\begin{array}{l}3 \text { large larvae } \\
0 \text { adult beetle }\end{array}$ & $\begin{array}{l}\text { large larvae } \\
0 \text { adult beetle }\end{array}$ & $\begin{array}{l}2 \text { large larvae } \\
0 \text { adult beetle }\end{array}$ & $\begin{array}{l}4 \text { large larvae } \\
0 \text { adult beetle }\end{array}$ \\
\hline \multirow{3}{*}{17.06 .16} & Weight (mg) & 8.2 & 8.7 & 8.0 & 17.7 \\
\hline & $\Delta$ weight $(\mathrm{mg})$ & 6.3 & 5.1 & 4.0 & 10.8 \\
\hline & No. of moults & 0 & 0 & 0 & 0 \\
\hline $2^{\text {st }}$ month & Consumption of $A$. punctatum & 0 large larvae & 1.5 large larvae & $2 \times 0.5$ large larvae & 0 large larva \\
\hline \multirow{3}{*}{21.07 .16} & Weight (mg) & 10 & 9.1 & 14.6 & 20.6 \\
\hline & $\Delta$ weight $(\mathrm{mg})$ & 1.8 & 0.4 & 6.6 & 2.9 \\
\hline & No. of moults & 0 & 1 & 1 & 1 \\
\hline $3^{\text {rd }}$ month & Consumption of $A$. punctatum & 1 large larva & 1 large larva & 2 large larvae & 2 large larvae \\
\hline \multirow{3}{*}{11.08 .16} & Weight $(\mathrm{mg})$ & 9.1 & 11.1 & 14.2 & 26.2 \\
\hline & $\Delta$ weight $(\mathrm{mg})$ & -0.9 & 2 & 0.4 & 5.6 \\
\hline & No. of moults & 0 & 0 & 0 & 0 \\
\hline $4^{\text {rd }}$ month & Consumption of $A$. punctatum & \multirow{4}{*}{$\begin{array}{l}\text { Died during } \\
4^{\text {th }} \text { month }\end{array}$} & 0 large larva & 0 large larva & 0 large larva \\
\hline \multirow{3}{*}{ 28.09.16 } & Weight $(\mathrm{mg})$ & & 12.1 & 11.8 & 23.4 \\
\hline & $\Delta$ weight $(\mathrm{mg})$ & & 1 & -2.4 & -2.8 \\
\hline & No. of molts & & 0 & 0 & 0 \\
\hline $5^{\text {th }}-9^{\text {th }}$ month & \multicolumn{5}{|c|}{ Placed in saw dust and transferred to cold conditions of $4^{\circ} \mathrm{C}$} \\
\hline \multirow{3}{*}{06.04 .17} & Weight $(\mathrm{mg})$ & & 11.2 & \multirow{8}{*}{$\begin{array}{l}\text { Death during } \\
\text { cold period }\end{array}$} & 17.6 \\
\hline & $\Delta$ weight $(\mathrm{mg})$ & & -0.9 & & -5.8 \\
\hline & No. of moults & & 1 & & 0 \\
\hline $10^{\text {th }}$ month & Consumption of $A$. punctatum & & 1 large larva & & 3 large larvae \\
\hline $11^{\text {th }}-12^{\text {th }}$ month & Consumption of $A$. punctatum & & 0 large larva & & \\
\hline $13^{\text {th }}$ month & No. of moults & & $\begin{array}{l}1 \text { pupated followed by } \\
\text { emergence of } 1 \text { adult }\end{array}$ & & Died during $11^{\text {th }}$ month \\
\hline $14^{\text {th }}-15^{\text {th }}$ month & & & Cold treatment of $4^{\circ} \mathrm{C}$ & & \\
\hline $16^{\text {th }}$ month & & & Adult emerged & & \\
\hline
\end{tabular}

$K$. caeruleus of the next generation (Table 2/2015a). Five larvae were detected, two of them were actively moving, one was motionless in a self-spun cocoon and two were dead, and several empty cocoons were found (Fig. 5 on the right). The two active larvae were both $7 \mathrm{~mm}$ long and weighed 6.4 and $8.5 \mathrm{mg}$, respectively. The dormant larva

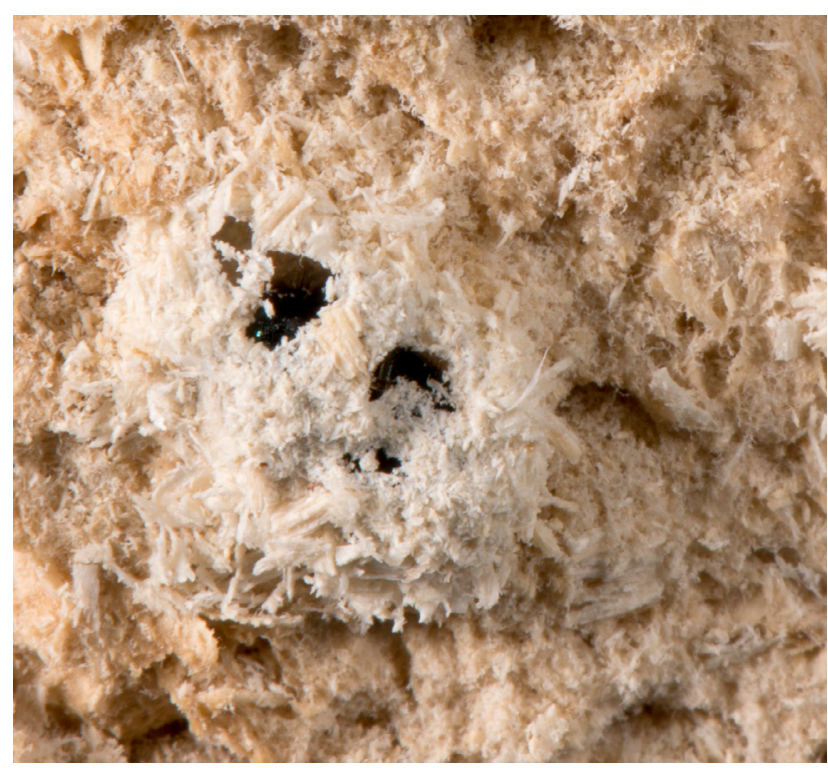

Fig. 4. Adult beetle of Korynetes caeruleus that has emerged from a pupa but is still in its cocoon. was carefully taken out of its cocoon. It weighed $10.3 \mathrm{mg}$ and was $9.0 \mathrm{~mm}$ long. Each larva was reintroduced into a new $A$. punctatum culture of equal age. Later this culture was transferred to cold conditions to induce dormancy and five months after returning it to standard rearing conditions it was examined. One of the three $K$. caeruleus had pupated inside a cocoon and the other two were dead. Finally, after one month the only live $K$. caeruleus was a fully sclerotized adult beetle of blue colour, which remained inside its cocoon for another four more months, when the next cold treatment was initiated. When returned to the standard rearing conditions the adult became active the next day.

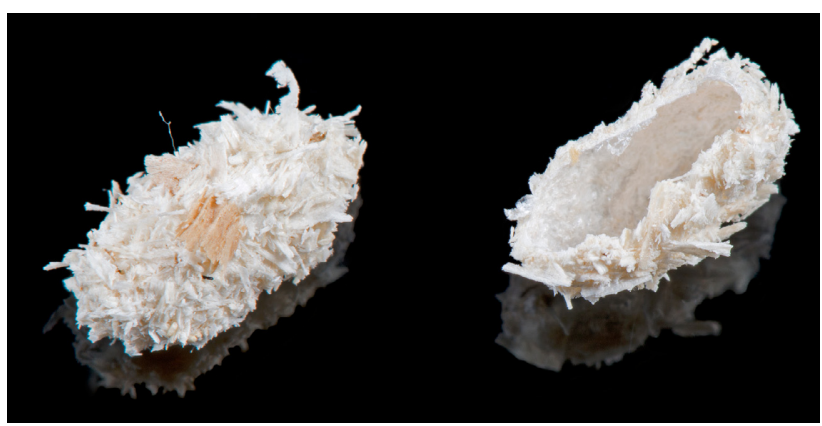

Fig. 5. Cocoons made by larvae of Korynetes caeruleus for pupation. The left cocoon is intact and encloses a pupa, the right one is partly destroyed and empty. 


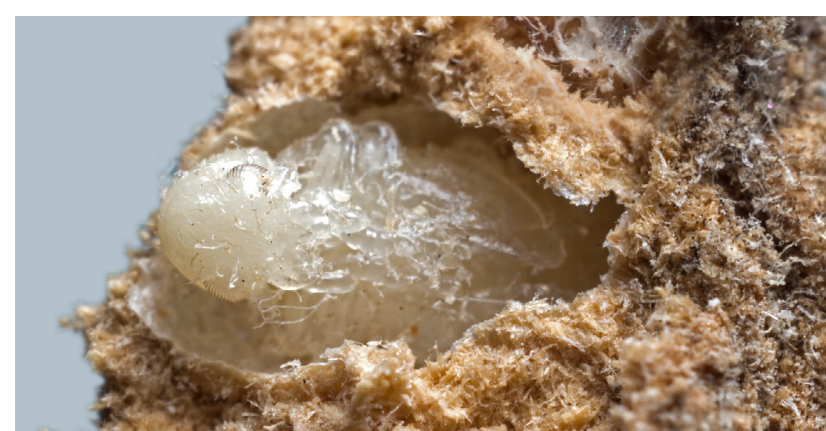

Fig. 6. Pupa of Korynetes caeruleus in an accidentally opened cocoon.

The rest of the 2015 cultures of $K$. caeruleus / A. punctatum were left undisturbed for one year before examining them (Table 2/2015b). These cultures were first subjected to cold treatment from the sixth to the eighth month. Twelve live larvae, and five pupae of $K$. caeruleus were detected. Eleven of the live larvae were in cocoons. Only one live larva $(2.9 \mathrm{mg}$ and $7 \mathrm{~mm})$ was active. The larvae in two of the cocoons that broke open during the examination of the cultures were $7 \mathrm{~mm}$ long and weighed 9.4 and $9.6 \mathrm{mg}$, respectively. All of the pupae were in the same kind of cocoon and one that was accessible weighed 9.0 mg (Fig. 5). All cocoons were placed in saw dust and kept at standard rearing conditions and one month later ten of the larvae had pupated. Only one developed into an adult beetle, which however remained inside its cocoon for the next three months, when the second cold treatment was initiated. When returned to standard rearing conditions this beetle emerged from its cocoon the next day. Of the five pupae, two produced adults, which remained inside their cocoons until the end of the second cold treatment, after which they emerged from their cocoons one and four days later, respectively. In addition, one adult beetle emerged before the second cold treatment. Thus, the 2015 cultures produced a total of five beetles, four of them emerged after the second cold treatment early in 2017 and one during the second season in 2016.

For the 2016 and 2017 cultures, the $K$. caeruleus beetles were placed on pieces of wood previously infested with larvae of A. punctatum. For the 2016 culture, the duration of the cold treatment was shortened to two months. However, this did not shorten the period to the emergence of active adults, because the beetles did not emerge immediately after the end of the cold treatment (Table 2/2016) as in the previous treatments (Table 2/2014 and Table 2/2015).

It appears that cold treatment is not the only stimulus inducing adult emergence. Under moderate conditions a period of about four months between the onset of dormancy and emergence of adult beetles from their cocoons seems equally important (see below). The second dormancy of the 2017 cultures was, therefore, scheduled for four months (Table 2/2017).

\section{Rearing larvae}

Larvae of $K$. caeruleus collected in churches in 2013, 2014, 2015 and 2017 (Table 1) were transferred to cultures

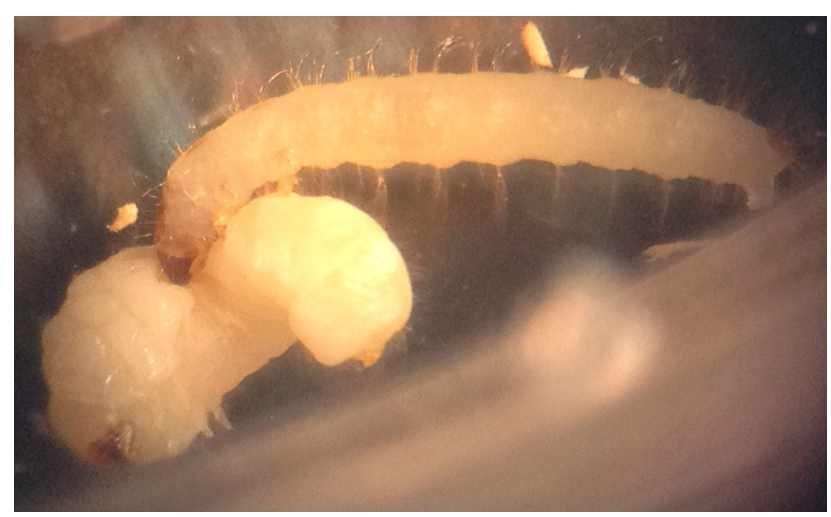

Fig. 7. Larva of Korynetes caeruleus attacking a larva of Anobium punctatum by inserting its mandibles into its soft abdominal tissues.

of $A$. punctatum larvae as described above. Food for $K$. caeruleus larvae collected in 2016 was provided in such a form that both larvae in diets and wood infested with $A$. punctatum larvae, were offered.

Four K. caeruleus larvae from the 2016 collection were kept separately in order to observe their feeding behaviour (see below). The size and weight of the $K$. caeruleus larvae collected in 2015, 2016 and 2017 did not differ statistically (Table 3).

Of the nine $K$. caeruleus larvae collected in 2013, six completed their development and emerged as adults (Table 4/2013) without being subjected to cold treatment.

Six larvae of $K$. caeruleus collected in 2014 survived the first two months and two of them survived a period of cold treatment (Table 4/2014). In the next season one of them completed development to the adult stage, remained in its cocoon during the following cold period and emerged immediately after the end of the cold treatment.

From the 2015 collection three adults emerged after the cold treatment, which they entered as dormant adults in their cocoons (Table 4/2015).

The 2016 collection of $K$. caeruleus larvae were left undisturbed and subjected to a cold period after six months and then on returning to standard rearing conditions three beetles emerged (Table 4/2016).

Korynetes caeruleus larvae collected in 2017 were examined three months later when eleven of them were dead. However, each of them had spun a cocoon in preparation for pupation.

In summary, the collected larvae of $K$. caeruleus were on average $7.1 \mathrm{~mm}$ long and weighed $3.3 \mathrm{mg}$. With presumably unlimited access to food in form of larvae of $A$. punctatum, larvae of $K$. caeruleus completed their development to the adult stage between six and twenty-two months after collection. Subjection to a period of cold triggered the emergence of the adult beetles that remained inside their cocoon after emerging from pupae. However, emergence of adults may also occur without their experiencing a period of cold (Table 4/2013).

\section{Feeding behaviour}

Four of the larvae of $K$. caeruleus collected in 2016 were kept individually in small arenas. They were continuously 


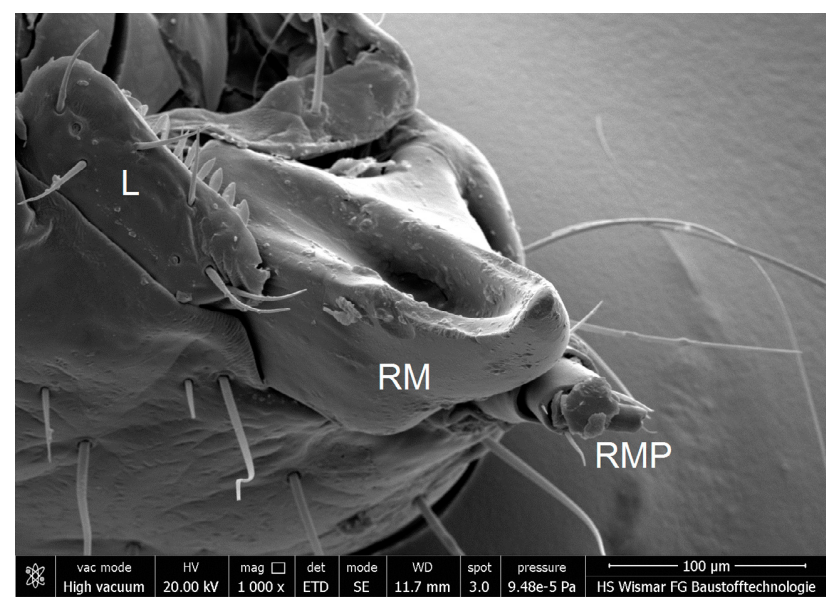

Fig. 8. SEM photograph of the head of a larva of Korynetes caeruleus. Dorsal/frontal view of the open right mandible (RM) showing its prominent proximal groove $(\mathrm{L}$ - labrum; RMP - right maxillar palpus).

fed with A. punctatum (Table 5). Food was successively replaced when previous larvae were completely or partially consumed.

When larvae of $K$. caeruleus were confined with one mature larva of $A$. punctatum in an arena, they initially sought refuge in the shelter provided for several minutes and then slowly moved around the arena. First contact with prey did not automatically result in an attack, even though all the $K$. caeruleus larvae had not been fed since they were collected. Eventually a larva of $K$. caeruleus initiated an attack by driving its sickle-like-mandibles into the abdomen of a larva of A. punctatum (Fig. 7). Due to their being in the open the larvae of $A$. punctatum were unable to escape. Observation under a binocular microscope at 10-fold magnification revealed pumping motions in the body of the predator once its mandibles penetrated the prey's cuticle. These repeated motions are interpreted as results of the muscular contractions involved in injecting digestive enzymes into the body cavity of the prey followed by the ingestion of predigested food. There is a depressed grove in the proximal part of each mandible (Fig. 8), which presumably function as a canal for injecting digestive enzymes into the prey's body and ingesting predigested food. The woodworm larvae markedly shrank during this process and finally the larva was consumed almost entirely. The entire process was not observed. However, it can readily be deduced from the subsequent absence of the body of the prey other than the indigestible parts, such as the head capsule and parts of the outer cuticle. Adult beetles of A. punctatum were also offered once, but after a week none had been attacked (Table 5, $1^{\text {st }}$ month).

At monthly intervals all the larvae of $K$. caeruleus were weighed to determine their gain in body mass and the number of moults were recorded (Table 5). When K. cearuleus larvae did not attack freshly offered food, they were provided with saw dust as refuge prior to transferring them to cold conditions of $4^{\circ} \mathrm{C}$, during which the surviving larvae burrowed into the saw dust, however, it is unclear when this occurred.

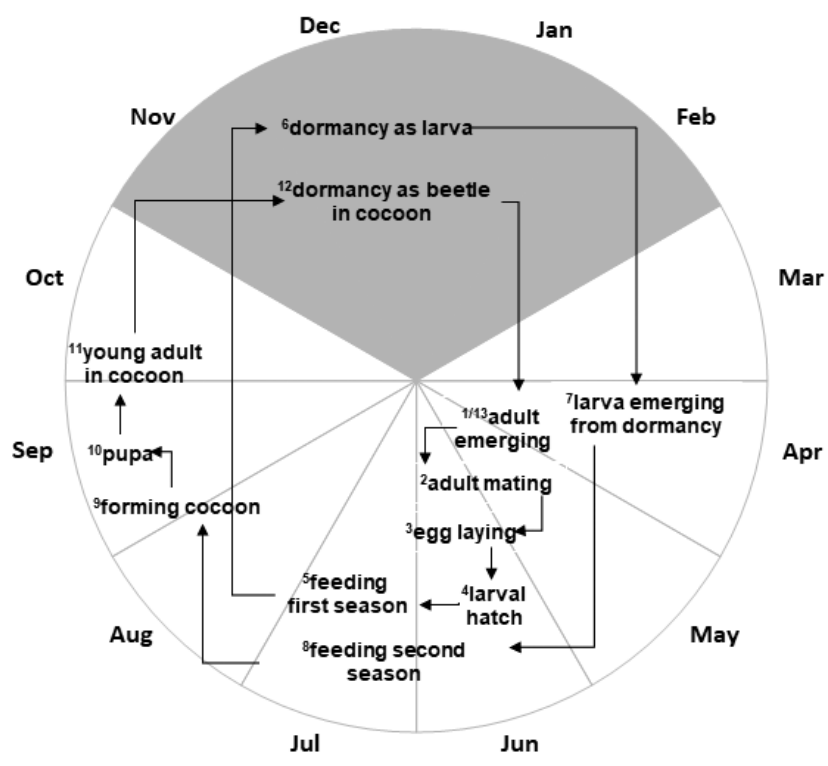

Fig. 9. Postulated two-year developmental cycle of Korynetes caeruleus with active life stages (white part of the pie-chart) and inactive dormant life stages (grey part of the pie-chart), starting with 1 "adult emerging" at the end of April and ending with 13 "adults emerging", which during the second cold treatment were dormant in their cocoons

After the cold treatment the larvae of $K$. caeruleus were acclimatized to ambient temperatures, weighed and fed larvae of $A$. punctatum (Table $5,10^{\text {th }}$ month). Finally, larva No. 2 spun a cocoon and pupated, which later developed into a soft skinned whitish imago and then a fully sclerotized blue coloured beetle. The adult beetle remained motionless inside the cocoon and was then subjected to a second cold period. When returned to standard rearing conditions, the imago emerged six days later.

In summary, $K$. caeruleus larvae readily and continually consumed larvae of $A$. punctatum. Some larvae moulted and larva No. 2 consumed six and a half $A$. punctatum larvae, moulted twice and increased in weight by $7.6 \mathrm{mg}$ before pupating and completing its development to the adult stage after being subjected to a cold period. Larva No. 4, which was also subjected to a cold period failed to pupate successfully but consumed eight larvae of A. punctatum, moulted twice and increased in weight by $10.7 \mathrm{mg}$ before starting to make a cocoon. Live adult beetles of $A$. punctatum were not attacked by larvae of $K$. caeruleus and dead adult beetles of $A$. punctatum were not offered (Ott, 2007).

\section{DISCUSSION}

Development of $K$. caeruleus does not follow a particular pattern. Like its most important prey A. punctatum and other wood boring beetles, $K$. caeruleus is also able to adapt its growth and moulting intervals to existing biotic and abiotic conditions (Amman, 1970; Ott, 2007; Petzoldt, 2011; Niehuis, 2013; Youssef et al., 2013). Within this range of conditions for development, it is likely we have identified the minimum requirements for the fastest possible life cycle under controlled laboratory conditions.

Our data indicates that in $K$. caeruleus the development from the mating of adults to the appearance of active adult 
beetles of the next generation takes two years (Fig. 9: $1-13$ ), given it is reared at $21^{\circ} \mathrm{C}$ and a relative humidity of approximately $75 \%$, and provided with sufficient food in the form of live prey larvae, shelter and subjected to two cold periods. Currently, we have not observed egg laying and only thirteen adult beetles have completed development under these laboratory conditions (Table 2). Some basic life history data revealed it takes approximately six months for the eggs to become larvae of about 7 to $9 \mathrm{~mm}$ in length and a weight of around $8 \mathrm{mg}$ (Fig. 9: 3-6). At this stage a larva is large enough to enter dormancy when subjected to a period of low temperature (Fig. 9: 6).

When returned to laboratory rearing conditions after approximately two to four months at a low temperature, larvae feed and complete their development in about six to eight months (Fig. 9: 7-8) then spin a cocoon (Fig. 9: 9), pupate (Fig. 9: 10) and, finally, emerge as an adult (Fig. 9: 11). However, if subjected to low temperature again, the adult beetles remain in their cocoons (Fig. 9: 12) and on returning to standard rearing conditions emerge from their cocoons after a few days (Fig. 9: 13).

Development lasted only one and a half to two seasons (10 months) with one cold period in between. The need for a second cold period seems to be facultative with young adults remaining inside their cocoons when temperatures start to decrease. A minimum duration of approximately three to four months appears optimal for the second cold period. Shortening the cold period did not result in an early emergence of adult beetles. If, however, the onset of declining temperature, which triggers the entering of dormancy, is delayed, e.g. by being transferred to favourable conditions in the laboratory, adult beetles may emerge at the end of the second season. This was recorded for three adults, two in the 2014 culture (Table 2/2014) and one in the 2015 culture (Table 2/2015b). Whether these "fast developers" could survive another cold period is unknown and needs further study.

The timing of development recorded accords with naturally occurring seasonal conditions if the mating of parental beetles occurs around mid to late spring as temperatures are increasing (Fig. 9: 2). Feeding and growth of larvae occurs from late spring to late summer. Before temperatures decrease in autumn, larvae have sufficient reserves to survive in a dormant state to the following year (Fig. 9: 6). The following spring these larvae start feeding again and prepare to complete their metamorphoses (Fig. 9: 7-11) at which time temperatures are slowly decreasing, which results in adult emergence being delayed to next spring (Fig. 9: 13). The second dormant phase in effect synchronizes adult emergence in the next season. Early emergence of adults in the field is therefore very unlikely. The observations of Haustein \& von Laar (2007) and Haustein (2010) on the occurrence of active larvae and beetles in old churches and those of Noldt (2007) in historic houses seem to fit this model.

Number and duration of the larval instars in $K$. caeruleus, however, are unknown. In the feeding experiments using large larvae (presumably in their second season) col- lected from churches, up to two additional larval moults were recorded before pupation. In other clerid beetles there are three larval instars before pupation (Amman, 1970, 1972; White \& Franklin, 1982). This might not apply to $K$. caeruleus, because it is unlikely that the young and small larvae moult only once in their first season.

However, it cannot be ruled out that the two moults of the old larvae in our experiments were an artefact due to an abundance of food. Three larval instars may be the minimum with more if conditions are unfavourable. As was the case reported by Haustein (2010) in which large second season larvae of $K$. caeruleus moulted up to six times without pupating and finally died. In this study, food was continuously available but there was nowhere where the larvae could construct pupal chambers. Without suitable material (wood, saw dust or similar material) larvae of $K$. caeruleus are probably incapable of forming and fixing cocoons for metamorphoses. Forming "free pupae" might not be possible and larvae continue to feed and grow and eventually die. When saw dust was provided in our feeding experiments, larvae of $K$. caeruleus stopped foraging for food and started to prepare cocoons.

The cocoon is made of a thin layer of a sticky whitish secretion. Inside wood, the secretion is attached to the inner wall of the pupal chamber, loosely surrounding the pupa inside. Becker (1942) postulates that K. caeruleus does not build a pupal chamber but readily lines old pupal chambers of $A$. punctatum or other anobiids with its secretion. In our experiments, when constructed in saw dust, small wooden particles adhered to the sticky outer surface and thus provided anchoring supports for the cocoon before it hardened (Fig. 5 left). The inner layer of a cocoon appears glossy (Fig. 5 right).

The feeding behaviour of larvae of $K$. caeruleus is best described as a combination of sucking haemolymph and consuming small body parts. This method of feeding is called extra-oral digestion (EOD) and is typical of many predaceous arthropods (Lövei \& Sunderland, 1996; Cohen, 1998). We recorded all the classical processes of EOD (Frazier et al., 1981; Cohen, 1995) when larvae of A. punctatum were provided as food. The sickle shaped mandibles of larvae of $K$. caeruleus with their depressed groove for injecting digestive enzymes are well suited for EOD and are similar morphologically to the mandibles of other predatory clerid larvae, e.g. Thanasimus dubius (White \& Franklin, 1982) and Dermestoides sanguinicollis (Kolibáč, 2002).

We present a method for rearing $K$. caeruleus successfully in the laboratory. Field collected adults and larvae should be placed on soft wood infested with all stages of A. punctatum. Rearing should be done at approximately $21^{\circ} \mathrm{C}$ and $75 \%$ relative humidity. A period at $4{ }^{\circ} \mathrm{C}$ lasting for four months should be provided after six months. This should be followed by another six months of rearing under standard condition and then a second period at $4{ }^{\circ} \mathrm{C}$ for four months. After which beetles can be expected to emerge, when cultures are returned to standard rearing conditions. Using this method the total time to reproduction in $K$. cae- 
ruleus is less than two years and could be even less than one and a half years, if the second cold period is shortened. When using artificial diets instead of wood, growth of mould and mites are a serious problem.

We are confident that it will be possible to mass produce $K$. caeruleus in the future and determine whether this beetle can be used as a biological control agent of $A$. punctatum. It is possible that the mass release of predators and parasitoids will reduce Anobium infestations in historical buildings, such as small churches in northern Germany, and provide the time necessary for obtaining the funding for sustainable restoration. Furthermore, it is likely that conventional pest control using biocides will become less popular in the future and IPM and biological pest control will increase in importance in the preservation of our cultural heritage.

\section{REFERENCES}

AleXander K.N.A. 2004: Revision of the Index of Ecological Continuity as Used for Saproxylic Beetles. English Nature Research Reports No. 574. English Nature, Peterborough, 61 pp.

Amman G.D. 1970: Prey consumption and variations in larval biology of Enoclerus sphegeus (Coleoptera: Cleridae). - Can. Entomol. 102: 1374-1379.

Amman G.D. 1972: Prey consumption and development of Thanasimus undatulus, a predator of the mountain pine beetle. Environ. Entomol. 1: 528-530.

Auer J. \& Kassel A. 2014: Braconid wasps: A biological control method for the common furniture beetle (Coleoptera: Anobiidae). In Müller G., Pospischil R. \& Robinson W.H. (eds): Proceedings of the 8th International Conference on Urban Pests. OOK-Press Kft., Veszprém, pp. 335-340.

BAKER J.M. \& BLETCHLY J.D. 1966: Prepared media for rearing the common furniture beetle Anobium punctatum (DeG) (Col. Anobiidae). - J. Inst. Wood Sci. 17: 53-57.

BECKER G. 1942: Ökologische und physiologische Untersuchungen über die holzzerstörenden Larven von Anobium punctatum De Geer. - Z. Morphol. Ökol. Tiere 39: 98-152.

BECKER G. 1954: Räuber und Parasiten holzzerstörender Insekten in Gebäuden. - Verh. Dt. Ges. Angew. Entomol. 1954: 76-86.

Belmain S.R. 1998: The Biology of the Deathwatch Beetle Xestobium rufovillosum De Geer (Coleoptera: Anobiidae). $\mathrm{PhD}$ Thesis, University of London, $202 \mathrm{pp}$.

Belmain S. \& Ridout B. 2000: The death-watch beetle - accommodated in all the best places. - Pestic. Outlook 7: 233-237.

Belmain S.R., Simmonds M.S.J. \& Blaney W.M. 1999a: Deathwatch beetle, Xestobium rufovillosum, in historical buildings: monitoring the pest and its predators. - Entomol. Exp. Appl. 93: $97-104$

Belmain S.R., Simmonds M.S.J. \& Blaney W.M. 1999b: The deathwatch beetle, Xestobium rufovillosum, accommodated in all the best places. In Robinson W.H., Rettich F. \& Rambo G.W. (eds): Proceedings of the 3rd International Conference on Urban Pests, 19-22 July 1999, Prague, Czech Republic. Czech University of Agriculture, Prague, pp. 407-414.

BIEBL S. \& Auer J. 2017: Practical use of braconid wasps for control of the common furniture beetle (Coleoptera: Anobiidae). In Davies M.P., Pfeiffer C. \& Robinson W.H. (eds): Proceedings of the Ninth International Conference on Urban Pests, Birmingham, UK, 9-12 July 2017. Aston University, Birmingham, pp. 367-375.

COHEN A.C. 1995: Extra-oral digestions in predaceous terrestrial arthropods. - Annu. Rev. Entomol. 40: 85-103.
CoHEN A.C. 1998: Solid-to-liquid feeding: The inside(s) story of extra-oral digestions in predaceous arthropods. - Am. Entomol. 44: 103-117.

Cymorek S. 1965: Verfahren zur beschleunigten Züchtung des Anobium punctatum im Laboratorium. In Freeman P. (ed.): Proceedings, $12^{\text {th }}$ International Congress of Entomology, London, 8-16 July, 1964. Royal Entomological Society, London, pp. 687-689.

CYMOREK S. 1975: Methoden und Erfahrungen bei Zucht von Anobium punctatum (De Geer). - Holz Roh- $u$. Werkstoff 33: 239-246.

EsSER J. \& KIELHORN K.-H. 2005: Ergebnisse der Untersuchungen zur Insektenfauna auf der Berliner Bahnbrache Biesenhorster Sand - Käfer (Coleoptera). - Märk. Entomol. Nachr. 3: 29-76.

FAULDS W. 1987: Improved techniques for the laboratory rearing of Thanasimus formicarius. - N. Z. J. Forest. Sci. 18: 187-190.

FinCH G.L. 2015: Recent records of scarce VC55 beetles. - LESOPS 31: 2-24.

FRANKE P. 2001: Holzwurmbefall tot oder lebend? - Prakt. Schädlingsbek. 6: 15-21.

Franzen C., Löther T. \& LuKasch J. 2009: Nutzungsorientierte, optimierte Lokaltemperierung von Kirchen - modellhafte Voruntersuchungen und Konzeptentwicklung. Deutsche Stiftung Umwelt (DBU) Projekt AZ 24824, Abschlussbericht, Dresden, $129 \mathrm{pp}$.

Frazier J.L., Nebeker T.E., Mizell R.F. \& Calvert W.H. 1981: Predatory behavior of the clerid beetle Thanasimus dubius (Coleoptera: Cleridae) on the southern pine beetle (Coleoptera: Scolytidae). - Can. Entomol. 113: 35-43.

GerstMEIER R. 1998: Checkered Beetles - Illustrated Key to the Cleridae of Western Palaearctic. Markgraf, Weikersheim, 300 pp.

Haustein T. 2010: Zur Diagnose und integrierten Bekämpfung Holz zerstörender Insekten unter Berücksichtigung der Buntkäfer (Coleoptera: Cleridae) als deren natürliche Gegenspieler in historischen Gebäuden. Fraunhofer IRB, Stuttgart, 175 pp.

HAUSTEIN T. \& von LAAR C. 2007: Vorkommen von synanthropen Buntkäfern (Coleoptera: Cleridae) in Mecklenburg-Vorpommern. - Entomol. Nachr. Ber. 51: 225-229.

Haustein T. von LaAR C. \& Noldt U. 2007: Situation of wooddestroying pests in historical buildings of Mecklenburg - insect monitoring. In Noldt U. \& Michels H. (eds): Wood-destroying Organisms in Focus - Alternative Measures for Preservation of Historic Buildings. Schriften des LWL-Freilichtmuseums Detmold Vol. 27, Westfälisches Landesmuseum für Volkskunde, Merkur, Detmold, pp. 73-81.

Haustein T., Haustein V., von Laar C. \& Noldt U. 2014: Bautenschutz vor Schädlingen - Lebensweise und Bestimmung von synanthropen Buntkäferarten. In Venzmer H. (ed.): Bautenschutz - Innovative Sanierungslösungen. Beuth, Berlin, pp. 189-200.

HÁva J. \& KovaŘík M. 2015: Results of a faunistic research to the families Cleridae, Trogossitidae and Lymexylonidae (Coleoptera) of "Údolí Únětického potoka Natural Reserve". - Elateridarium 9: 118-122.

Hickin N.E. 1963a: The Insect Factor in Wood Decay. Hutchinson, London, $336 \mathrm{pp}$.

HickIN N.E. 1963b: The Woodworm Problem. Hutchinson, London, $123 \mathrm{pp}$.

Johansson H. 2011: Comparison of Saproxylic Beetle Assemblages on four Different Broad-leaved Tree Species in Southeastern Sweden. MSc. Thesis, University Linköping, 26 pp. 
Kassel A., Opitz C. \& Auer J. 2018: Retrospect, insights and foresights: Biological control of Anobium punctatum with Spathius exarator. In Adler C.S. et al. (eds): Proceedings of the 12th International Working Conference on Stored Product Protection (IWCSPP), Berlin, Germany, 7-11 October, 2018. Julius-Kühn-Archiv No. 463. Julius Kühn Institut, Quedlinburg, pp. 419-424.

KoliBÁČ J. 2002: Description of a larva of Dermestoides sanguinicollis (Fabricius, 1782) (Coleoptera, Cleridae, Korynetinae). - Acta Mus. Morav. (Sci. Biol.) 87: 41-45.

Lövei G.L. \& SunderLand K.D. 1996: Ecology and behavior of ground beetles (Coleoptera: Carabidae). - Annu. Rev. Entomol. 41: 231-256.

Mosneagu M. 2012: The preservation of cultural heritage damaged by anobiids (Insecta, Coleoptera, Anobiidae). - Acad. Roman. Sci. Ann. (Biol. Sci.) 1: 32-65.

Müller J., Bussler H., Gossner M., Gruppe A., Jarzabek-MülLer A., Preis M. \& Rettelbach T. 2007: Forest edges in the mixed-montane zone of the Bavarian Forest National Park hot spots of biodiversity. - Silva Gabr. 13: 121-148.

Nienuis M. 2013: Die Buntkäfer in Rheinland-Pfalz und im Saarland. GNOR, Mainz, 684 pp.

Nikitsky N.B. \& Schigel D.S. 2004: Beetles in polypores of the Moscow region: checklist and ecological notes. - Entomol. Fenn. 29: 6-22.

NoldT U. 2007: Monitoring of wood-destroying insects - requirements and first results. In Noldt U. \& Michels H. (eds): Wood-destroying Organisms in Focus - Alternative Measures for Preservation of Historic Buildings. Schriften des LWLFreilichtmuseums Detmold Vol. 27, Westfälisches Landesmuseum für Volkskunde, Merkur, Detmold, pp. 41-57.

OstrausKas H. \& Ferenca R. 2010: Beetles (Coleoptera) caught in traps baited with pheromones for Dendroctonus rufipennis (Kirby) (Curculionidae: Scolytinae) in Lithuania. — Ekologija 56: $41-46$.

Отт R. 2007: Spurensuche - Untersuchungen über die Entstehung von Bohrmehlhäufchen an Schlupflöchern des Gemeinen Nagekäfers. - Nachrbl. Landesdenkmalpfl. Baden-Württemb. 36: 164-167.

Paul F., Prozell S. \& SchÖLler M. 2008: Monitoring of natural enemies of the furniture beetle Anobium punctatum (L., 1758) (Coleoptera: Anobiidae). - Mitt. Dt. Ges. Allgem. Angew. Entomol. 16: 323-326.
Petzoldt S. 2011: Feldbeobachtungen von Antagonisten Holz zerstörender Insekten und Pilze und deren Erscheinungsform. In Mankel W. (ed.): Proceedings EIPOS Holzschutz. Dresden, pp. 19-37.

QUERNER P. 2017: Biological control with larval parasitoid Lariophagus distinguendus in museums and historic buildings. In Davies M.P., Pfeiffer C. \& Robinson W.H. (eds): Proceedings of the Ninth International Conference on Urban Pests, Birmingham, UK, 9-12 July 2017. Aston University, Birmingham, pp. 359-366.

Reeve J.D., Rojas M.G. \& Morales-Ramos J.A. 2003: Artificial diet and rearing methods for Thanasimus dubius (Coleoptera: Cleridae), a predator of bark beetles (Coleoptera: Scolytidae). - Biol. Contr. 27: 315-322.

SCHÖLLER M. 2010: Biological control of stored-product insects in commodities, food processing facilities and museums. In Carvalho M.O. et al. (eds): Proceedings of the 10th International Working Conference on Stored Product Protection, 27 June - 2 July 2010, Estoril, Portugal. Julius-Kühn-Archiv No. 425. Julius Kühn Institut, Berlin, pp. 596-606.

SCHÖLlER M. \& PROZELl S. 2011: Biological control of cultural heritage pest Coleoptera and Lepidoptera with the help of parasitoid Hymenoptera. - J. Entomol. Acarol. Res. 43: 157-168.

Steidle J.L.M., Gantert C., Noldt U., Prozell S. \& Schöller M. 2007: Biocontrol of wood-destroying beetles by mass release of a parasitoid wasp: fiction and facts. In Noldt U. \& Michels H. (eds): Wood-destroying Organisms in Focus - Alternative Measures for Preservation of Historic Buildings. Schriften des LWL-Freilichtmuseums Detmold Vol. 27, Westfälisches Landesmuseum für Volkskunde, Merkur, Detmold, pp. 163-172.

Unger A., SChNiewind A.P. \& Unger W. 2001: Conservation of Wood Artifacts. Springer, Berlin, 578 pp.

VITÉ J.P. 1952: Die holzzerstörenden Insekten Mitteleuropas. Musterschmidt, Göttingen, 155 pp.

White R.A. JR. \& Franklin R.T. 1982: External morphology of larval Thanasimus dubius (Fabricius) (Coleoptera: Cleridae). - Coleopt. Bull. 36: 143-152.

Youssef N.A., Mostafa F.F.M. \& Khalil H.R. 2013: Biological studies on the predator, Tarsostenus univittatus Rossi (Coleoptera: Cleridae) of the powder post beetle, Lyctus africanus Lesene (Coleoptera: Lyctidae). - Egypt. J. Biol. Pest Contr. 23: 295-299.

Received June 20, 2019; revised and accepted September 23, 2019 Published online November 4, 2019 